\title{
Comparative Study between Ethanolic and $\beta$-Cyclodextrin Assisted Extraction of Polyphenols from Peach Pomace
}

\author{
Nada El Darra (D), ${ }^{1}$ Hiba N. Rajha, ${ }^{2}$ Espérance Debs, ${ }^{3}$ Fatima Saleh, ${ }^{1}$ Iman El-Ghazzawi, ${ }^{1}$ \\ Nicolas Louka, ${ }^{2}$ and Richard G. Maroun ${ }^{2}$ \\ ${ }^{1}$ Faculty of Health Sciences, Beirut Arab University, Tarik El Jedidah, Riad El Solh, P.O. Box 115020, Beirut 1107 2809, Lebanon \\ ${ }^{2}$ Unité de Recherche Technologies et Valorisation Agro-Alimentaire, Centre d'Analyses et de Recherche, Faculté des Sciences, \\ Université Saint-Joseph, Riad El Solh, BP 11-514, Beirut 1107 2050, Lebanon \\ ${ }^{3}$ Faculty of Sciences, Department of Biology, University of Balamand, Koura, Lebanon
}

Correspondence should be addressed to Nada El Darra; n.aldarra@bau.edu.lb

Received 22 September 2017; Revised 4 January 2018; Accepted 31 January 2018; Published 8 March 2018

Academic Editor: Salam A. Ibrahim

Copyright (C) 2018 Nada El Darra et al. This is an open access article distributed under the Creative Commons Attribution License, which permits unrestricted use, distribution, and reproduction in any medium, provided the original work is properly cited.

\begin{abstract}
Peach byproducts are often regarded as food waste despite their high content in health-promoting components. Amongst the latter, polyphenols are bioactive molecules with significant health benefits. The present study investigated an eco-friendly and costeffective method using a GRAS food additive, $\beta$-cyclodextrin $(\beta-\mathrm{CD})$, for the recovery of polyphenols from peach pomace. $\beta$-CD assisted extraction of polyphenols was compared to that of conventional solvent (ethanol) extraction at the same concentrations $(10 \mathrm{mg} / \mathrm{mL}, 20 \mathrm{mg} / \mathrm{mL}, 30 \mathrm{mg} / \mathrm{mL}, 40 \mathrm{mg} / \mathrm{mL}$, and $50 \mathrm{mg} / \mathrm{mL})$ in terms of quality (antiradical activity) and quantity. The extract obtained by $50 \mathrm{mg} / \mathrm{mL} \beta$-CD assisted extraction showed the highest polyphenol $(0.72 \mathrm{mg}$ GAE/g DM) and flavonoid (0.35 mg catechin/g of DM) concentrations as maximal antiradical activity (6.82\%) and a noted antibacterial activity. Our results showed the competitiveness of $\beta$-CD assisted extraction to recover a high quantity and quality of polyphenols from peach pomace suggesting $\beta$-CD as a green alternative method for phenolic extraction.
\end{abstract}

\section{Introduction}

Byproducts and waste obtained from food processing represent a major disposal problem for the food industry. A large number of these products are generated at different stages of the food supply chain of either vegetable or animal commodities [1]. Currently, waste management bodies are highly recommending that industrialists invest in new enduses for such food byproducts. Valorisation of food waste sources is therefore becoming a prime interest, owing to their environmental and economic values. For instance, natural oils extracted from fruit seeds and kernels are used in cosmetics and pharmaceutical industry [2].

Peach (Prunus persica L.) is a fruit rich in polyphenols that are mainly localized in the pulp and peel tissues. Chlorogenic acid, catechin, epicatechin, rutin, and cyanidin-3-glucoside represent the main phenolic compounds of this fruit [3]. Although it is rich in ascorbic acid and carotenoids, it was found that the phenolic content of the peach is the major contributor to the observed antioxidative activity [4]. It is noteworthy to mention that, in China (mainland), $10^{5} \mathrm{MT}$ (Metric Ton) of peach pomace has been at least estimated to be produced annually from peach juice processing [5].

In the present study, we are interested in the recovery of polyphenols from the peach pomace, as the studies related to peach polyphenols are very limited in the literature. Adil and coworkers [6] have optimized the subcritical extraction of phenolic content from peach pomace which was performed by selecting the pressure between 20 and $60 \mathrm{MPa}$, temperature between 40 and $60^{\circ} \mathrm{C}$, ethanol concentration at $14-20 \mathrm{wt} . \%$, and extraction time from 10 to $40 \mathrm{~min}$ on subcritical $\left(\mathrm{CO}_{2}+\right.$ ethanol $)$ extraction of polyphenol. The total phenolic content from peach pomace was $0.26 \mathrm{mg}$ gallic acid equiv./g and the antiradical efficiency was $1.5 \mathrm{mg} 1,1-$ diphenyl-2-picrylhydrazyl (DPPH)/mg [6].

Traditionally, extraction of phenolic compounds from natural resources is carried out using organic solvents, for example, methanol, ethanol, and acetone [7]. However, these 
extraction processes are quite laborious and involve large amounts of solvents associated with serious environmental issues, thus limiting their application. The need to develop new and cost-effective methods used to extract high levels of polyphenols with enhanced bioavailability from products such as peach turns out to be urgent. There is an increasing demand in recent years for cheaper, safer, and ecofriendly alternatives to organic solvents. Cyclodextrins (CDs) based extraction is an emerging "green" technology of great potential. CDs are naturally occurring cyclic oligosaccharides arising from the degradation of starch and are FDA "Food and Drug Administration" approved [8]. They appear as $\alpha-, \beta$-, and $\gamma$-CDs, knowing that $\beta$-CDs are the least expensive and the most widely used [9]. $\beta$-CDs are increasingly employed as encapsulating agents for plants bioactive molecules such as polyphenols, hence preserving their biological properties, extending their shelf life, and protecting them away from environmental factors (light, temperature, oxidation, $\mathrm{pH}$, and moisture) [9-11]. Compared to organic solvents, $\beta$-CDs assisted extraction is more economic, safe, and green [12].

A recent study conducted by Rajha and collaborators [13] has clearly shown the capacity of $\beta$-CD to extract polyphenols from vine shoots with a higher radical scavenging capacity compared to conventional ethanol extraction. Similarly, Ratnasooriya and Rupasinghe [14] demonstrated that the assisted recovery of total phenolic compounds from grape pomace slurry using $\beta$-CD at room temperature was significantly higher compared to water extraction [14]. Diamanti and coworkers [15] also reported that green extraction using $\beta$ $\mathrm{CD}$ enhanced the total phenolic content and the radical scavenging activity of whole pomegranate extracts [15].

To the best of our knowledge, there are no available studies on the use of CDs in recovering polyphenols from peach pomace. The aim of this study was to compare the efficiencies of polyphenols extraction using $\beta$-CD, aqueous and organic solvents. The extraction processes were optimized by monitoring solvent concentration, temperature, solvent volume to sample ratio, and extraction time. The resulting extracts were then analysed for total phenolic content, flavonoids, tannins, vitamin $\mathrm{C}$, and carotenoids contents. In addition, these compounds were examined for their antioxidant and antimicrobial activity.

Finally, high-performance liquid chromatography (HPLC) was implemented to identify the phenolic components present in every extract.

\section{Materials and Methods}

2.1. Samples Preparation and Dry Matter Content. Peach (Prunus persica L.) pomace was obtained from Conserves Modernes Chtaura (Chtaura, Lebanon) specialized in the production of jams and purees. The pomace consists of pressed skins and pulp residue. The dry matter content for the raw material was determined by weighing an appropriate amount of sample and drying it for 24 hours in a ventilated oven at $105^{\circ} \mathrm{C}[16]$.

2.2. Chemicals. All chemicals were purchased from Fluka Chemie GmbH (Buchs, Switzerland) or from Sigma-Aldrich (Steinheim, Germany).
2.3. Bacterial Strains, Culture Media, and Growth Conditions. Sixteen stock isolates of bacterial strains were used. They are clinical isolates obtained from previous research studies carried out in the Faculty of Medicine of Alexandria University, Egypt. The isolates included two strains of each of the following: Methicillin-resistant Staphylococcus aureus (MRSA), Methicillin-resistant Staphylococcus epidermidis (MRSE), coagulase-negative staphylococci, Staphylococcus aureus, high-level aminoglycoside-resistant enterococci (HLAR) (Enterococcus faecalis and Enterococcus faecium which were also resistant to vancomycin), Pseudomonas aeruginosa, and Escherichia coli. One strain of Klebsiella pneumoniae and Acinetobacter baumannii was also studied. The two strains of Escherichia coli, Klebsiella pneumoniae, and Acinetobacter baumannii were previously proved to be extended-spectrum $\beta$-lactamases (ESBL), by double-disc synergy and combined-disc tests.

2.4. Solid-Liquid Extraction Process. The extraction process of polyphenols from peach pomace was performed with a solid-liquid ratio of $1: 10(\mathrm{w} / \mathrm{v})$. After $\beta$-CD aqueous extraction at different concentrations $(10,20,30,40$, and $50 \mathrm{mg} / \mathrm{mL})$ and ethanol extraction at different concentrations (10, 20, $30,40,50$, and $500 \mathrm{mg} / \mathrm{mL}$ ), the extracts were centrifuged at $5000 \mathrm{rpm}$ (rotation per minute) for $15 \mathrm{~min}$. $\beta$-CD aqueous concentrations were prepared by dissolving the required weight of $\beta$-CD in the specific water volume in a $50^{\circ} \mathrm{C}$ water bath while stirring for 2 hours of diffusion time [13].

\subsection{Total Phenolic Content Determination: Folin-Ciocalteu} Method. The total phenolic content was determined according to Folin-Ciocalteu (FC) method [17]. $0.2 \mathrm{~mL}$ of standard (gallic acid) or diluted sample, $1.0 \mathrm{~mL}$ of $\mathrm{FC}$ reagent, and $0.8 \mathrm{~mL}$ of $\mathrm{Na}_{2} \mathrm{CO}_{3}$ solution (7.5\%) were mixed and allowed to stand for 2 hours at room temperature. Light absorption was measured at $750 \mathrm{~nm}$ by a spectrophotometer UV-VIS against a blank similarly prepared, but containing distilled water instead of extract. The total phenolic content $\left(Y_{e}\right)$ was expressed in grams of gallic acid equivalent (GAE) per gram of dry matter (DM) (g GAE/g DM).

2.6. Determination of Tannin Concentration. Total tannin content $(\mathrm{g} / \mathrm{L})$ and $\mathrm{HCl}$ index which represents the tannin polymerization degree were determined according to Ribérau-Gayon and collaborators [18]. Total tannin assay is based on the heating process of tannins in acidic medium leading to the formation of cyanidins. Two tubes were prepared, each containing $1 \mathrm{~mL}$ of diluted peach pomace extract, $0.5 \mathrm{~mL}$ of water, and $1.5 \mathrm{~mL}$ of $12 \mathrm{~N} \mathrm{HCl}$. The first tube was mixed and heated in a water bath at $100^{\circ} \mathrm{C}$ for $30 \mathrm{~min}$. The second was kept at room temperature. Following the rapid cooling, $0.25 \mathrm{~mL}$ of ethanol was added to the mixture and the resulting absorbance was recorded at $520 \mathrm{~nm}$.

The tannin concentration was calculated as follows:

Tannin concentration $(\mathrm{mg} / \mathrm{L})$

$=19.33 \times \Delta$ optical densities. 
2.7. Free Radical Scavenging Activity. The 1,1-diphenyl-2picrylhydrazyl (DPPH) radical was used in the present study for the screening of the radical scavenging activity of the extracts [19]. The DPPH radical scavenging activity was measured using the spectrophotometer UV-VIS (Libra S32, Biochrom, France). The samples were tested at a concentration of $20 \mathrm{mg} / \mathrm{mL}$ and then mixed with $1000 \mu \mathrm{L}$ of $0.1 \mathrm{mM}$ DPPH-ethanol solution and $450 \mu \mathrm{L}$ of $50 \mathrm{mM}$ Tris-HCl buffer ( $\mathrm{pH}$ 7.4). Methanol $(50 \mu \mathrm{L})$ was used for blank measurements in this experiment. After $30 \mathrm{~min}$ of incubation at room temperature, the reduction of the DPPH free radical was measured by reading the absorbance at $517 \mathrm{~nm}$. Butylhydroxytoluene (BHT) (a synthetic antioxidant) was used as a positive control. The inhibition ratio (percent) was calculated according to the following equation:

$$
\begin{aligned}
\% & \text { inhibition } \\
= & {\left[\frac{(\text { absorbance of control }- \text { absorbance of test sample })}{\text { absorbance of control }}\right] } \\
& * 100 .
\end{aligned}
$$

2.8. Determination of Total Flavonoids (TF). The total flavonoids (TF) assay was conducted as previously described by Zhuang and coworkers [20] with some modification [20]. A volume of $1 \mathrm{~mL}$ of diluted extract or standard solution of catechin was placed in a $10 \mathrm{~mL}$ volumetric flask already containing $4 \mathrm{~mL}$ of $\mathrm{H}_{2} \mathrm{O}$. Five minutes later, $0.3 \mathrm{~mL}$ of $\mathrm{NaNO}_{2}$ (5\%) and $1.5 \mathrm{~mL}$ of $\mathrm{AlCl}_{3}(2 \%)$ were added. The mixture was shaken for $5 \mathrm{~min}$, then $2 \mathrm{~mL}$ of $1 \mathrm{M}$ solution of $\mathrm{NaOH}$ was added, and the mixture was well shaken again. The absorbance was measured at $510 \mathrm{~nm}$ against the blank. The results were calculated according to the calibration curve for catechin $\left(R^{2}=0.99\right)$. The content of TF was expressed as $\mathrm{mg}$ of catechin equivalent (CE) per g of dry matter content.

2.9. Vitamin C Analysis. Vitamin C estimation was done according to the Folin-Ciocalteu method [21]. Peach pomace extracts $(0.2 \mathrm{~mL})$ were added to $0.8 \mathrm{~mL}$ of $10 \%$ trichloroacetic acid and then well shaken. The mixtures were kept on ice for $5 \mathrm{~min}$ and then centrifuged at $3000 \mathrm{~g}$ for $5 \mathrm{~min}$. The extract was then diluted (1/10). Folin-Ciocalteu was diluted (1/10) and then $0.2 \mathrm{~mL}$ was added to the mixture and vigorously shaken. After $10 \mathrm{~min}$, at room temperature, the absorbance was measured at $760 \mathrm{~nm}$ against distilled water as a blank and vitamin $\mathrm{C}$ was estimated through the calibration curve of the ascorbic acid standard.

2.10. $\beta$-Carotene Estimation. A simple UV spectrophotometric method was used for the analysis of $\beta$-carotene. The extraction of $\beta$-carotene was simply assessed on the liquid extracts by UV absorbance which was measured at $461 \mathrm{~nm}$. The following equation was applied to determine the $\beta$ carotene concentration: $y=0.1069 x-0.0057$, where $x$ and $y$ are, respectively, the $\beta$-carotene concentration in $\mathrm{mg} / \mathrm{L}$ and $\mathrm{UV}$ absorption at $461 \mathrm{~nm}$ [22].

2.11. Determination of Minimum Inhibitory Concentration (MIC). The broth microdilution method was used in a sterile 96-well microtiter plate (U shaped base) [23].
2.11.1. Preparation of the Bacterial Inocula for MIC. Glycerol broth stocks were subcultured on a freshly prepared blood agar plate, incubated at $37^{\circ} \mathrm{C}$ overnight. Using a sterilized loop, five colonies of each strain were inoculated in $3 \mathrm{~mL}$ of cation adjusted Mueller Hinton broth, and the turbidity was compared to $0.5 \mathrm{McF}$ arland standard. 1/100 dilution of this 0.5 McFarland was prepared to be used for the MIC.

\subsubsection{Peach Phenolic Extracts Preparation for MIC Assess-} ment. The peach ethanolic extracts at different concentrations $(10,20,30,40,50$, and $500 \mathrm{mg} / \mathrm{mL})$ were subjected to drying by rotary evaporator, in order to remove the ethanol. Afterwards, five serial dilutions, in sterile distilled water, of each of the following extracts were prepared: aqueous extract, $\beta$-cyclodextrin extract $(50 \mathrm{mg} / \mathrm{mL})$, ethanolic extract $(50 \mathrm{mg} / \mathrm{mL})$, and ethanolic extract $(500 \mathrm{mg} / \mathrm{mL})$ until reaching the concentrations $53 \mu \mathrm{g} / \mathrm{mL}, 26 \mu \mathrm{g} / \mathrm{mL}, 13 \mu \mathrm{g} / \mathrm{mL}$, $6 \mu \mathrm{g} / \mathrm{mL}$, and $3 \mu \mathrm{g} / \mathrm{mL}$. After the addition of equal volumes $(100 \mu \mathrm{L})$ of each concentration of these extracts to the bacterial strains $(100 \mu \mathrm{L})$ to be tested in each well of the plate, the final concentrations of the different phenolic extracts were reduced to $26 \mu \mathrm{g} / \mathrm{mL}, 13 \mu \mathrm{g} / \mathrm{mL}, 6.5 \mu \mathrm{g} / \mathrm{mL}$, $3.25 \mu \mathrm{g} / \mathrm{mL}$, and $1.6 \mu \mathrm{g} / \mathrm{mL}$. Four microtiter plates were used in this experiment. After overnight incubation at $37^{\circ} \mathrm{C}$, all the plates were examined for the MIC of each of the phenolic extracts concentration that inhibits the bacterial growth. All the peach phenolic extracts were filter sterilized using $0.4 \mu \mathrm{m}$ disposable syringe filters prior to the assessment.

2.12. High-Performance Liquid Chromatography with Diode Array Detection (HPLC-DAD) Analysis. Polyphenol analyses were performed using a Jasco HPLC system (Japan) (PV2089) equipped with an autosampler, an L-2130 pump, a Jetstream column oven, and an L-2450 diode array detector. The separation was carried out with a Column C18 $25 \times$ $0.46 \mathrm{~mm}$ (Teknokroma Professional Friendly Lichrospher $100 \mathrm{RP} 185 \mu \mathrm{M}, 25 \times 0.46$, serial number NF-21378, Barcelona, Spain), using a gradient elution at a flow rate of $1 \mathrm{~mL}$ per min for $30 \mathrm{~min}$. Trans-cinnamic acid, caffeic acid, hydroxybenzoic acid, chlorogenic acid, catechin, rutin, quercetin, protocatechin, gallic acid, epigallocatechin, kaempferol, catechin gallate, and myricetin standards were used for identification and quantification purposes with HPLC-DAD, respectively. The mobile phase consisted of acidified nanopure water at pH 2.3 with $\mathrm{HCl}(\mathrm{A})$ and acetonitrile HPLC grade (B). The elution was isocratic conditions from 0 to $5 \mathrm{~min}$ with $85 \%$ $\mathrm{A}$ and $15 \% \mathrm{~B}$. Gradient from 5 to $30 \mathrm{~min}$ began with $85 \%$ $\mathrm{A}$ and $15 \% \mathrm{~B}$ and ended with $0 \% \mathrm{~A}$ and $100 \% \mathrm{~B}$ followed by isocratic conditions from 30 to $35 \mathrm{~min}$ with $0 \% \mathrm{~A}$ and $100 \% \mathrm{~B}$ to reequilibrate the column. The injection volume was $10 \mu \mathrm{L}$. The identification of peaks was based on retention time and the spectra of external standards. The concentration of phenolic compounds was determined from standard curves constructed for individual compounds by injecting different concentrations of corresponding standards [24].

2.13. Statistical Analysis. Each experiment was conducted in duplicate and analysis repeated twice. Means and standard deviations of data were calculated. The error bars in all 


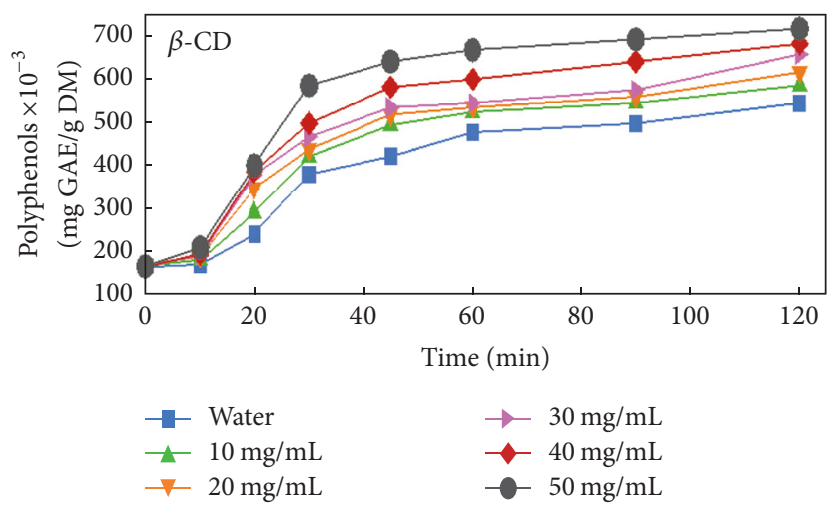

(a)

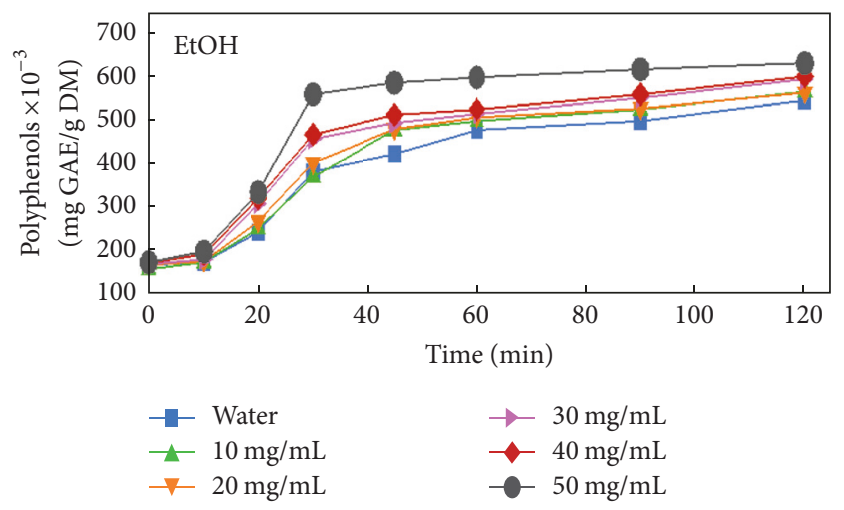

(b)

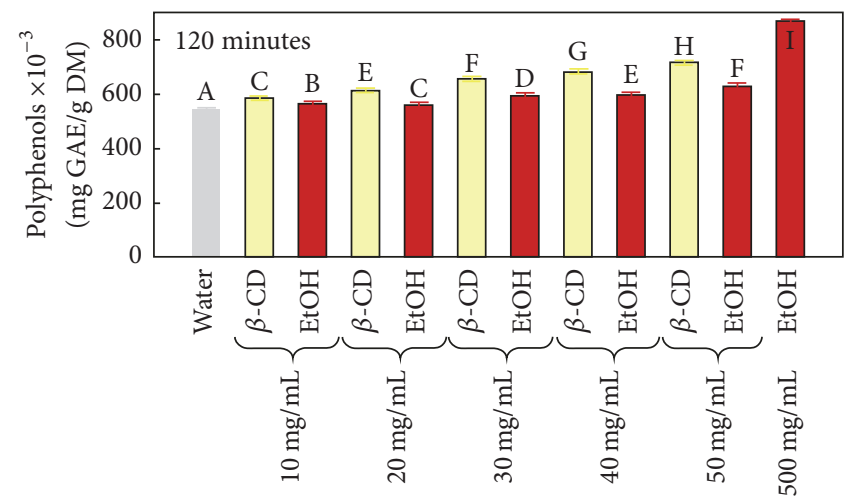

(c)

FIGURE 1: (a) Extraction kinetics of polyphenols with different concentrations $(0,10,20,30$, 40, and $50 \mathrm{mg} / \mathrm{mL})$ of beta-cyclodextrin $(\beta$ $\mathrm{CD})$ and (b) different concentrations $(0,10,20,30,40$, and $50 \mathrm{mg} / \mathrm{mL})$ of ethanol (EtOH). (c) Comparison of polyphenol recovery with both solvents $(\beta-\mathrm{CD}$ and $\mathrm{EtOH})$ at the same concentrations after 120 minutes of extraction. Different superscript letters indicate significant statistical difference $(p<0.05)$.

figures correspond to the standard errors. Variance analyses (ANOVA) and Least Significant Difference (LSD) test were conducted to evaluate the significant differences between the results. STATGRAPHICS ${ }^{\circledR}$ Centurion XV (StatPoint Technologies, Inc.) was used to perform statistical analysis.

\section{Results and Discussion}

3.1. Effect of Ethanolic and Beta-Cyclodextrin Assisted Extractions on the Phenolic Content, Tannins, and Flavonoids of the Peach Pomace Extract. Figure 1 shows the recovery of polyphenols from peach pomace by solid-liquid extraction using $\beta$-CD or EtOH solvents. Many parameters affect the solid-liquid extraction process. One of these parameters is the extraction time that had to be studied before undertaking the trials. For this purpose, a systematic study, between 0 and 120 minutes, was conducted for the recovery of total phenolic content (TPC) using the three extraction media: water, beta-cyclodextrin, and ethanol at different concentrations. In Figures 1(a) and 1(b), we noticed that the longer the extraction time, the better the TPC yield. Moreover, a closer observation of the plots revealed a common kinetics pattern of extraction for the three solvents. All the kinetics followed a classical three-step model. A slight increase in the TPC yield was observed during the first ten minutes of the extraction process. Less than $20 \%$ increase was recorded for the best datum. Then a second step occurred where a sharp rise of the extraction efficiency is clearly noticed. The TPC yield was around 3-fold higher at $30 \mathrm{~min}$ compared to $10 \mathrm{~min}$. Finally, the slope decreased significantly between 30 and $120 \mathrm{~min}$ where the recovery capacity had plateaued out with barely $30 \%$ of improvement. To stretch out the argument, this model could strongly reflect what is happening at the microscopic level (Figure 1(c)). Step one marks the time needed by the solvent to diffuse inside the cellular structure and to prepare the biological material for the subsequent step. Step two represents the highest extraction efficiency of the cellular content in TPC. Step three witnesses an almost stabilization of the extraction yield, which means that the three solvents would have reached their maximum capacity of extraction under those conditions rather than unveiling the maximum cellular content in TPC.

On a different note, it is noteworthy to mention that the effect of the concentration of both solvents $\beta$-CD and ethanol was directly proportional to the TPC yield. The tested solvents were used over a concentration range of 10 to $50 \mathrm{mg} / \mathrm{mL}$; the higher the concentration, the better the TPC yield. Water was significantly the least efficient in TPC extraction. 


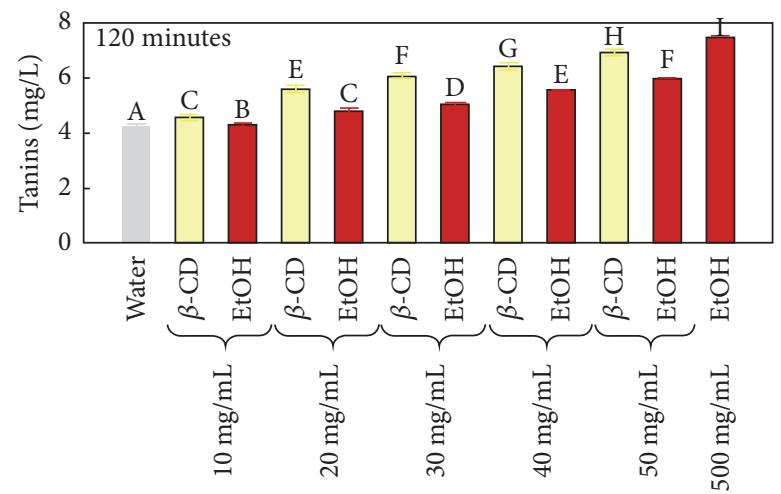

(a)

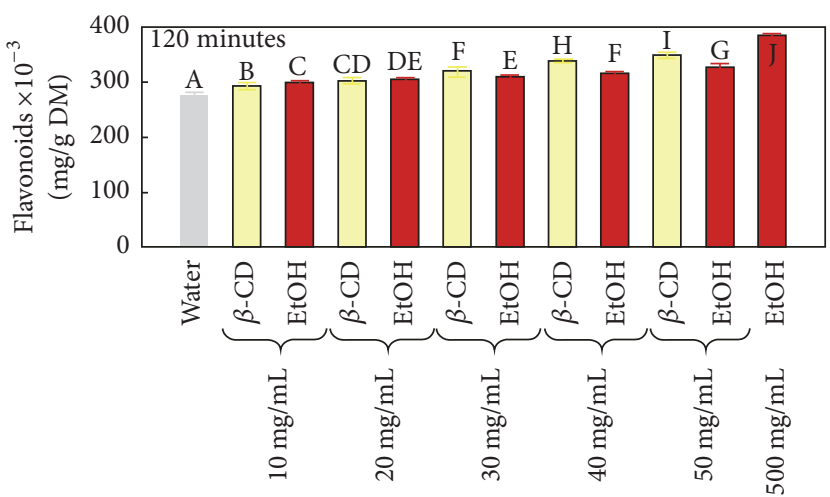

(b)

Figure 2: Comparison of (a) tannins and (b) flavonoids recovery using $\beta$-CD and EtOH at the same concentrations after 120 minutes of extraction. Different superscript letters indicate significant statistical difference $(p<0.05)$.

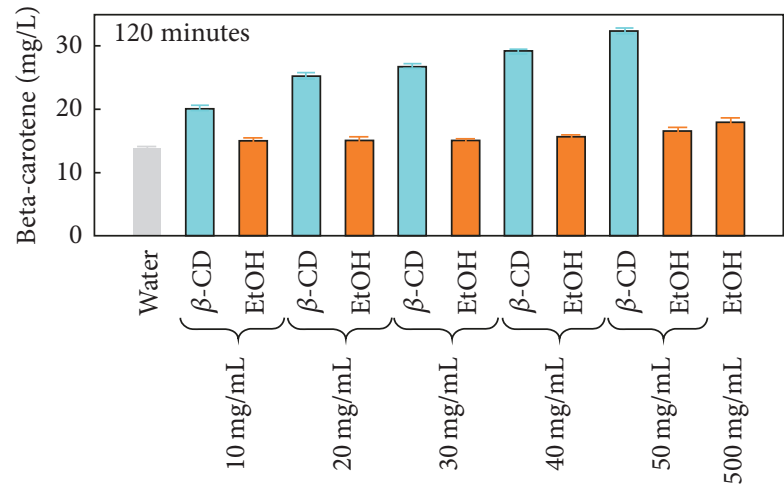

(a)

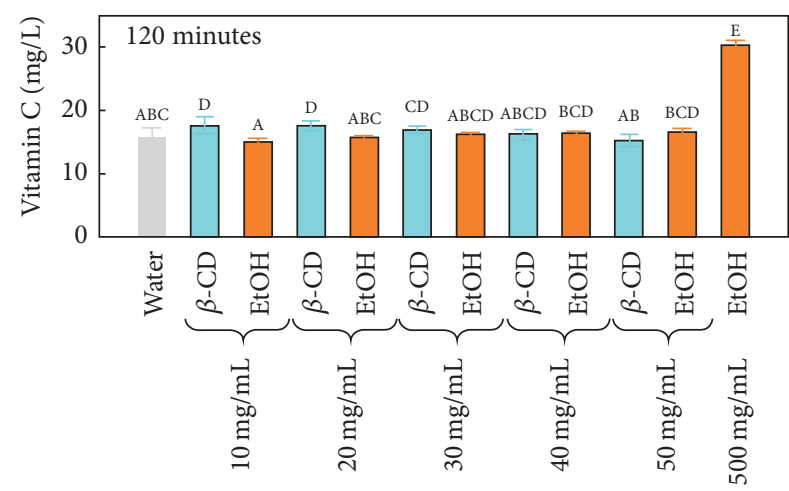

(b)

Figure 3: Comparison of (a) beta-carotene and (b) vitamin $\mathrm{C}$ recovery using $\beta$-CD and EtOH at the same concentrations after 120 minutes of extraction. Different superscript letters indicate significant statistical difference $(p<0.05)$.

The increase in both $\beta-\mathrm{CD}$ and $\mathrm{EtOH}$ concentrations up to $50 \mathrm{mg} / \mathrm{mL}$ significantly $(p<0.05)$ enhances polyphenol extraction compared to water solvent (Figures 1(a) and $1(b))$. However, at the same concentrations, $\beta$-CD is more efficient than the organic solvent EtOH. For example, at $50 \mathrm{mg} / \mathrm{mL}$ of both solvents, polyphenol yields were 715 and $630 \mathrm{mg} \mathrm{GAE} / \mathrm{g} \mathrm{DM}$ for $\beta-\mathrm{CD}$ and $\mathrm{EtOH}$, respectively. The highest polyphenol concentration was obtained with $500 \mathrm{mg} / \mathrm{mL}$ EtOH ( $865 \mathrm{mg} \mathrm{GAE} / \mathrm{g}$ DM). However, compared to $50 \mathrm{mg} / \mathrm{mL}$ EtOH, the concentration was enhanced by only 1.2 times with an increase of tenfold EtOH concentration.

In concordance with total polyphenol extraction, tannins and flavonoids recovery from peach pomace was also enhanced by $\beta$ - $\mathrm{CD}$ and $\mathrm{EtOH}$ compared to the aqueous extraction. At all the studied concentrations $(10,20,30,40$, and $50 \mathrm{mg} / \mathrm{mL}$ ), $\beta$-CD was more efficient than $\mathrm{EtOH}$ (Figures $2(\mathrm{a})$ and $2(\mathrm{~b}))$. $\beta$-CD efficacy compared to water is likely due to the inclusion complexes it forms with bioactive molecules, which increases their solubility and therefore their recovery (Szente, L. et al., 2004, [9]). On the other hand, ethanol efficiency is rather related to the alteration it causes to the cellular membranes which increases their permeability and therefore the diffusion process of intracellular components [25].

3.2. Effect of Ethanolic and Beta-Cyclodextrin Assisted Extraction on Beta-Carotene and Vitamin C Content of the Peach Pomace Extract. Figure 3 shows the recovery of betacarotene and vitamin $\mathrm{C}$ from peach pomace with increasing $\beta$ - $\mathrm{CD}$ and $\mathrm{EtOH}$ concentrations. $\beta$-CD ameliorates by far the extraction of beta-carotene compared to EtOH. For example, $50 \mathrm{mg} / \mathrm{mL}$ of $\beta$-CD permits the obtainment of a better betacarotene yield $(32 \mathrm{mg} / \mathrm{L})$ than $500 \mathrm{mg} / \mathrm{mL}$ of EtOH $(18 \mathrm{mg} / \mathrm{L})$. In contrast, vitamin C extraction was not enhanced $(16 \mathrm{mg} / \mathrm{L})$ by $\beta$-CD or EtOH addition up to $50 \mathrm{mg} / \mathrm{mL}$. This result is in agreement with the study of Navarro et al., 2011, who showed that the addition of $\beta$-CD produces low or null effect on the vitamin $\mathrm{C}$ content of pasteurized orange juice. The highest vitamin C yield $(30 \mathrm{mg} / \mathrm{L})$ was obtained with $500 \mathrm{mg} / \mathrm{mL}$ of EtOH.

3.3. Antiradical Activity of the Peach Pomace Extracted by Ethanolic and Beta-Cyclodextrin Assisted Extraction. Since no amelioration of vitamin $\mathrm{C}$ extraction was observed in 


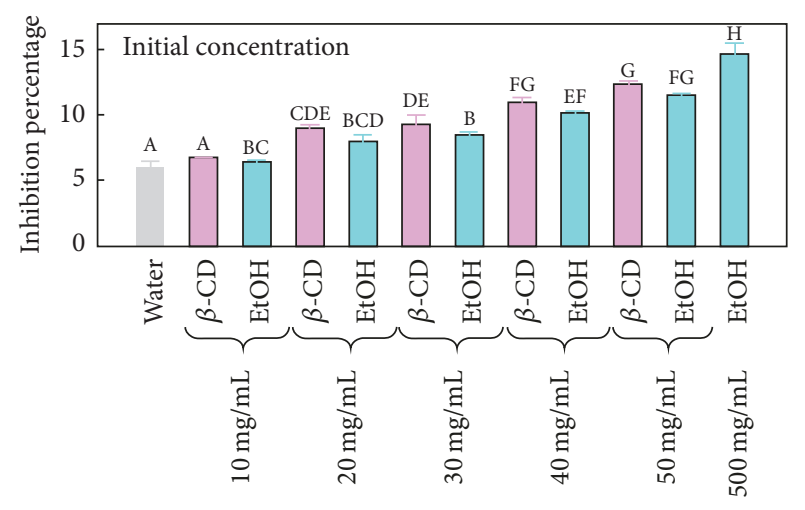

(a)

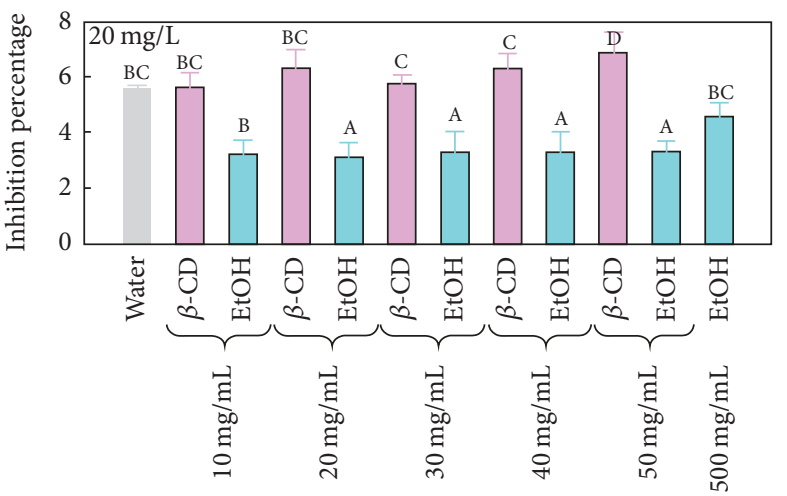

(b)

Figure 4: Comparison of the radical scavenging capacity of $\beta$-CD and EtOH extracts (a) at their initial concentration and (b) at $20 \mathrm{mg} / \mathrm{mL}$ of polyphenols. Different superscript letters indicate significant statistical difference $(p<0.05)$.

water, $\beta$-CD, and EtOH concentrations up to $50 \mathrm{mg} / \mathrm{mL}$ (Figure $3(\mathrm{~b}))$, the radical scavenging capacity of those extracts was therefore attributed to their polyphenol and beta-carotene contents. This was in accordance with the study of Cantín et al., 2009, who showed no correlation between vitamin C and antiradical activity [26]. Figure 4(a) shows the inhibition percentage of the DPPH radical obtained with the different extracts at their initial polyphenol concentrations shown in Figure 1. The higher the polyphenol concentration in the extracts, the better their antiradical capacity was. Many authors showed the concentration-dependent radical scavenging activity of polyphenol extracts $[27,28]$. At the same polyphenol concentration (Figure $4(\mathrm{~b})$ ), all $\beta$-CD extracts showed better antiradical capacity than those obtained with EtOH suggesting a better quality of the recovered molecules. The efficiency of $\beta$-CD in terms of polyphenol extraction and the enhancement of their radical scavenging capacity was also shown on vine shoots [13]. Similar study showed that microencapsulation of Mexican oregano essential oils with $\beta$-cyclodextrin enhanced their antiradical activity [29]. This is attributed to the protection effect of polyphenol encapsulation by $\beta$-CD since it is likely to preserve them from heat-degradation, UV light, and oxidation [30].

\subsection{Antibacterial Activity of the Peach Pomace Extracted} by Ethanolic and Beta-Cyclodextrin Assisted Extraction. The antimicrobial activities of the three peach pomace extracts ( $\beta$-CD $50 \mathrm{mg} / \mathrm{mL}$, EtOH $50 \mathrm{mg} / \mathrm{mL}$, and EtOH $500 \mathrm{mg} / \mathrm{mL}$ ) were tested against different Gram-positive and Gramnegative bacterial strains (Table 1) using MIC at different concentrations $1.6,3.25,6.5,13$, and $26 \mu \mathrm{g} / \mathrm{mL}$. The ethanol extract $(500 \mathrm{mg} / \mathrm{mL})$ of peach pomace showed the highest inhibitory activity against the different tested Gram-positive and Gram-negative strains. Our results are in accordance with the study by Zarai et al. [31] who showed that ethanolic extracts were more effective against both Gram-positive and Gram-negative bacteria tested, which could be explained by a better extraction of phenolic and flavonoid components at ethanolic concentration of $500 \mathrm{mg} / \mathrm{mL}$ [31]. This could be probably due to the fact that ethanol at a high concentration of $500 \mathrm{mg} / \mathrm{mL}$ is more selective in extracting polyphenols with higher biological activity. This was consistent with our radical scavenging activity and flavonoids findings, where ethanol $500 \mathrm{mg} / \mathrm{mL}$ showed the higher inhibitor activity of $\mathrm{DPPH}$ with high flavonoids content. Other extracts $(\beta-\mathrm{CD}$ $50 \mathrm{mg} / \mathrm{mL}, \mathrm{EtOH} 50 \mathrm{mg} / \mathrm{mL}$ ) were found to be active against all the tested species of Gram-positive bacteria whereas the Gram-negative bacteria remained unaffected. Our results are in agreement with the findings of $\mathrm{Naz}$ et al. [32] who showed that phenolic compounds have enhanced activity against Gram-positive strains compared to Gram-negative [32], due to the presence of an outer membrane in the cell wall of Gram-negative strains acting as permeability barrier and thus reducing the uptake [33]. Compared to $\mathrm{EtOH} 50 \mathrm{mg} / \mathrm{mL}, \beta$ CD $50 \mathrm{mg} / \mathrm{mL}$ in water showed lower MIC for the different Gram-positive strains, which leads to a higher antibacterial activity. The ethanol was used to be compared at the same concentration as $\beta-C D$, since it is a solvent with relatively low toxic potential, and use of ethanol was permitted in the food industry [34]. The recovery of polyphenols possessing a higher antibacterial activity was noted for $\beta$-CD $50 \mathrm{mg} / \mathrm{mL}$ assisted extraction comparing to EtOH $50 \mathrm{mg} / \mathrm{mL}$. This could be due to a better encapsulation and activity of polyphenols in $\beta$-CD $50 \mathrm{mg} / \mathrm{mL}$, leading to a higher antibacterial activity.

\subsection{Polyphenol Quantification by High-Performance Liquid} Chromatography. Polyphenol quantity and diversity were also determined by HPLC on water, $\beta$-CD $(50 \mathrm{mg} / \mathrm{mL})$, and $\mathrm{EtOH}$ (50 and $500 \mathrm{mg} / \mathrm{mL}$ ) extracts (Figure 5). $\beta$-CD selectively enhances the extraction of gallic and caffeic acids with yields equal to 220 and $328 \mu \mathrm{g} / \mathrm{g}$ DM, respectively. $500 \mathrm{mg} / \mathrm{mL}$ of EtOH was required to reach the same gallic and caffeic acids' yields. The higher concentrations of these phenolic acids in $\beta$-CD $(50 \mathrm{mg} / \mathrm{mL})$ and $\mathrm{EtOH}(500 \mathrm{mg} / \mathrm{mL})$ could explain their high antibacterial activities against the bacterial strains stated above [35], as well as their high scavenging activity against the DPPH radical [36]. However, water seems to better extract protocatechin $(7188 \mu \mathrm{g} / \mathrm{g} \mathrm{DM})$ compared to EtOH $50 \mathrm{mg} / \mathrm{mL}(3561 \mu \mathrm{g} / \mathrm{g} \mathrm{DM})$ and $\mathrm{EtOH}$ $500 \mathrm{mg} / \mathrm{mL}$ (4899 $\mu \mathrm{g} / \mathrm{g}$ DM). 
TABLE 1: Minimum inhibitory concentration $(\mu \mathrm{g} / \mathrm{mL})$ of different Gram + and Gram - bacteria obtained with $\beta-\mathrm{CD} 50 \mathrm{mg} / \mathrm{mL}$, EtOH $50 \mathrm{mg} / \mathrm{mL}$, and EtOH $500 \mathrm{mg} / \mathrm{mL}$ extracts.

\begin{tabular}{|c|c|c|c|}
\hline \multirow{2}{*}{ Bacteria/POMs } & \multicolumn{3}{|c|}{ Minimum inhibitory concentration $(\mu \mathrm{g} / \mathrm{mL})$} \\
\hline & $\beta-\mathrm{CD} 50 \mathrm{mg} / \mathrm{mL}$ & EtOH $50 \mathrm{mg} / \mathrm{mL}$ & EtOH $500 \mathrm{mg} / \mathrm{mL}$ \\
\hline Methicillin-resistant Staphylococcus aureus (MRSA1) (Gram +) & 13 & 26 & 13 \\
\hline Methicillin-resistant Staphylococcus aureus (MRSA2) (Gram +) & 26 & - & 1.5 \\
\hline Methicillin-resistant Staphylococcus epidermidis MRSE 1297 (Gram +) & - & - & 1.5 \\
\hline Methicillin-resistant Staphylococcus epidermidis MRSE 1296 (Gram +) & - & - & 6.5 \\
\hline Coagulase-negative staphylococci $1664($ Gram +$)$ & - & - & 13 \\
\hline Coagulase-negative staphylococci $1530($ Gram +) & 13 & - & 13 \\
\hline Staphylococcus aureus $1966($ Gram +) & 6.5 & 13 & 13 \\
\hline Staphylococcus aureus 2030 (Gram +) & 3 & 13 & 13 \\
\hline High-level aminoglycoside-resistance enterococci HLAR (Gram +) & 13 & - & 13 \\
\hline Vancomycin-resistant enterococci VRE $($ Gram +$)$ & 13 & - & 1.5 \\
\hline Pseudomonas aeruginosa $27(\mathrm{Gram}-)$ & - & - & 1.5 \\
\hline Pseudomonas aeruginosa 32 (Gram -) & - & - & 1.5 \\
\hline Escherichia coli $1238($ Gram -) & - & - & 13 \\
\hline Escherichia coli $1250($ Gram -) & - & - & 13 \\
\hline Klebsiella pneumoniae 184 (Gram -) & - & - & 6.5 \\
\hline Acinetobacter baumannii 1204 (Gram -) & - & - & 1.5 \\
\hline
\end{tabular}

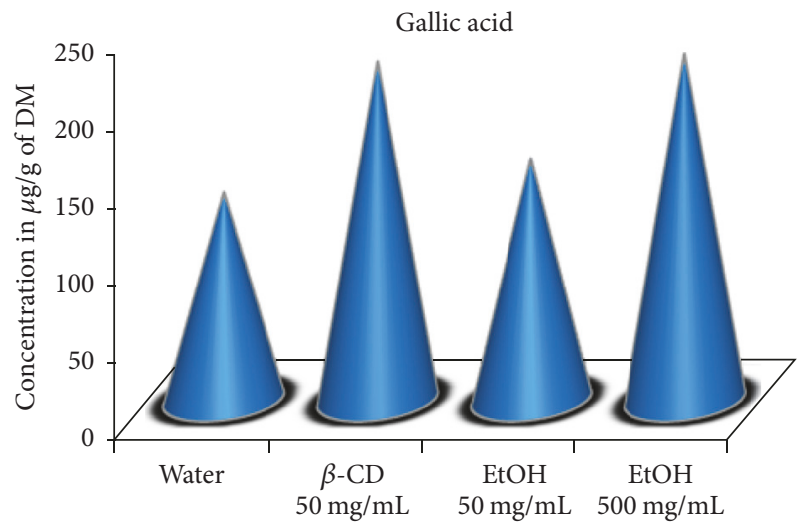

(5\%) $\quad(50 \%)$

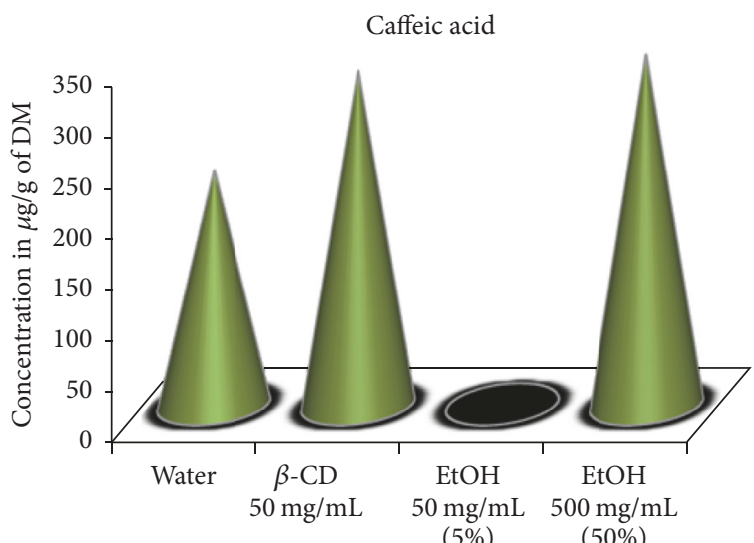

$(5 \%)$

$(50 \%)$

Protocatechin

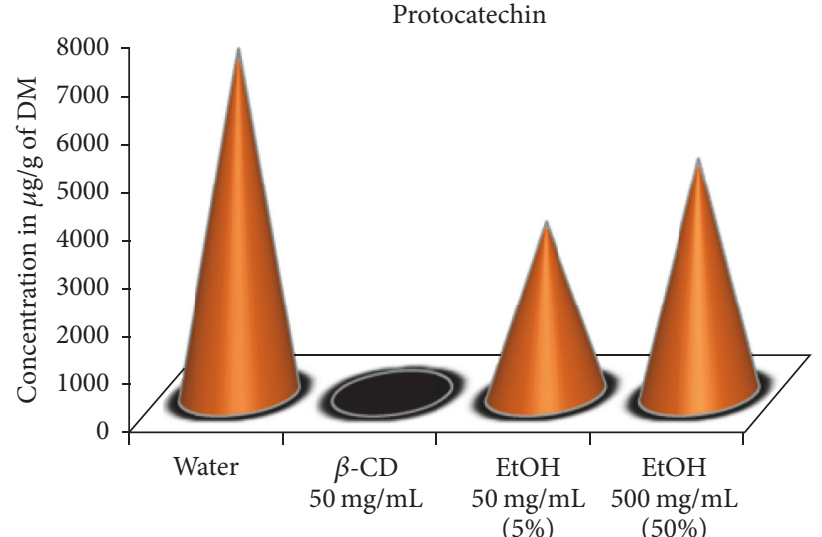

Figure 5: Gallic acid, caffeic acid, and protocatechin content of water, $\beta$-CD (50 mg/mL), EtOH (50 mg/mL), and EtOH (500 mg/mL) extracts. 


\section{Conclusion}

Our study demonstrated that $\beta$-CD assisted extraction of peach pomace enhanced the phenolic content, tannins, flavonoids, carotenoids, antiradical, and antimicrobial activities compared to organic solvent extraction. Our study verified that encapsulation of peach pomace polyphenols in $\beta$-CD is efficient in terms of the quantity and quality of the extracted molecules. The use of $\beta-C D$ in an assisted extraction process is a green technology for food waste recovery.

\section{Disclosure}

This work was presented as an oral presentation in " 15 th International Conference on Food Processing \& Technology" in Italy 2016.

\section{Conflicts of Interest}

The authors declare that they have no conflicts of interest.

\section{Authors' Contributions}

Both Nada El Darra and Hiba N. Rajha equally contributed to this work.

\section{References}

[1] J. Gustavsson, C. Cederberg, U. Sonesson et al., "Global food losses and food waste: extent, causes and prevention," in Proceedings of the International Congress: Save Food, vol. 38, 2011.

[2] C. M. Galanakis, "Recovery of high added-value components from food wastes: conventional, emerging technologies and commercialized applications," Trends in Food Science \& Technology, vol. 26, no. 2, pp. 68-87, 2012.

[3] C. Andreotti, D. Ravaglia, A. Ragaini, and G. Costa, "Phenolic compounds in peach (Prunus persica) cultivars at harvest and during fruit maturation," Annals of Applied Biology, vol. 153, no. 1, pp. 11-23, 2008.

[4] M. I. Gil, F. A. Tomás-Barberán, B. Hess-Pierce, and A. A. Kader, "Antioxidant capacities, phenolic compounds, carotenoids, and vitamin $\mathrm{C}$ contents of nectarine, peach, and plum cultivars from California," Journal of Agricultural and Food Chemistry, vol. 50, no. 17, pp. 4976-4982, 2002.

[5] H. Xu, Q. Jiao, F. Yuan, and Y. Gao, "Invitro binding capacities and physicochemical properties of soluble fiber prepared by microfluidization pretreatment and cellulase hydrolysis of peach pomace," LWT- Food Science and Technology, vol. 63, no. 1, pp. 677-684, 2015.

[6] I. H. Adil, H. I. Çetin, M. E. Yener, and A. Bayindirli, "Subcritical (carbon dioxide + ethanol) extraction of polyphenols from apple and peach pomaces, and determination of the antioxidant activities of the extracts," The Journal of Supercritical Fluids, vol. 43, no. 1, pp. 55-63, 2007.

[7] R. N. Mariano, D. Alberti, J. C. Cutrin, S. G. Crich, and S. Aime, "Design of PLGA based nanoparticles for imaging guided applications," Molecular Pharmaceutics, vol. 11, pp. 4100-4106, 2014.
[8] U.S. Food and Drug Administration, "Food additive status list," 2016, http://www.fda.gov/food/ingredientspackaginglabeling/ foodadditivesingredients/ucm091048.

[9] E. Pinho, M. Grootveld, G. Soares, and M. Henriques, "Cyclodextrins as encapsulation agents for plant bioactive compounds," Carbohydrate Polymers, vol. 101, no. 1, pp. 121-135, 2014.

[10] N. Kalogeropoulos, K. Yannakopoulou, A. Gioxari, A. Chiou, and D. P. Makris, "Polyphenol characterization and encapsulation in $\beta$-cyclodextrin of a flavonoid-rich Hypericum perforatum (St John's wort) extract," LWT - Food Science and Technology, vol. 43, no. 6, pp. 882-889, 2010.

[11] M. Shulman, M. Cohen, A. Soto-Gutierrez et al., "Enhancement of naringenin bioavailability by complexation with hydroxypropoyl- $\beta$-cyclodextrin," PLoS ONE, vol. 6, no. 4, Article ID e18033, 2011.

[12] C. D. Santos, P. Buera, and F. Mazzobre, "Novel trends in cyclodextrins encapsulation, Applications in food science," Current Opinion in Food Science, 2017.

[13] H. N. Rajha, S. Chacar, C. Afif, E. Vorobiev, N. Louka, and R. G. Maroun, " $\beta$-cyclodextrin-assisted extraction of polyphenols from vine shoot cultivars," Journal of Agricultural and Food Chemistry, vol. 63, no. 13, pp. 3387-3393, 2015.

[14] C. C. Ratnasooriya and H. P. V. Rupasinghe, "Extraction of phenolic compounds from grapes and their pomace using $\beta$ cyclodextrin," Food Chemistry, vol. 134, no. 2, pp. 625-631, 2012.

[15] A. C. Diamanti, P. E. Igoumenidis, I. Mourtzinos, K. Yannakopoulou, and V. T. Karathanos, "Green extraction of polyphenols from whole pomegranate fruit using cyclodextrins," Food Chemistry, vol. 214, pp. 61-66, 2017.

[16] M. A. Madrau, A. Piscopo, A. M. Sanguinetti et al., "Effect of drying temperature on polyphenolic content and antioxidant activity of apricots," European Food Research and Technology, vol. 228, no. 3, pp. 441-448, 2009.

[17] K. Slinkard and V. L. Singleton, "Total phenol analysis: automation and comparison with manual methods," American Journal of Enology and Viticulture, vol. 28, no. 1, pp. 49-55, 1977.

[18] P. Ribéreau-Gayon, D. Dubourdieu, B. Donèche, and A. Lonvaud, Traité d'Enologie, Tome 1: Microbiologie du Vin, Vinifications, Dunod, Paris, 1998.

[19] W. Brand-Williams, M. E. Cuvelier, and C. Berset, "Use of a free radical method to evaluate antioxidant activity," LWT - Food Science and Technology, vol. 28, no. 1, pp. 25-30, 1995.

[20] B. Zhuang, L.-L. Dou, P. Li, and E.-H. Liu, "Deep eutectic solvents as green media for extraction of flavonoid glycosides and aglycones from Platycladi Cacumen," Journal of Pharmaceutical and Biomedical Analysis, vol. 134, pp. 214-219, 2017.

[21] S. K. Jagota and H. M. Dani, "A new colorimetric technique for the estimation of vitamin C using folin phenol reagent," Analytical Biochemistry, vol. 127, no. 1, pp. 178-182, 1982.

[22] P. Karnjanawipagul, W. Nittayanuntawech, P. Rojsanga, and L. Suntornsuk, "Analysis of beta-carotene in Carrot by Spectrophotometer," Mahidol University Journal of Pharmaceutical Science, vol. 37, no. 8, 2010.

[23] J. M. Andrews, "Determination of minimum inhibitory concentrations," Journal of Antimicrobial Chemotherapy, vol. 48, no. 1, pp. 5-16, 2001.

[24] M. Vizzotto, W. Porter, D. Byrne, and L. Cisneros-Zevallos, "Polyphenols of selected peach and plum genotypes reduce cell viability and inhibit proliferation of breast cancer cells while not affecting normal cells," Food Chemistry, vol. 164, pp. 363-370, 2014. 
[25] D. B. Goldstein and J. H. Chin, "Interaction of ethanol with biological membranes," Federation Proceedings, vol. 40, pp. 2073-2076, 1981.

[26] C. M. Cantín, M. A. Moreno, and Y. Gogorcena, "Evaluation of the antioxidant capacity, phenolic compounds, and vitamin $\mathrm{C}$ content of different peach and nectarine (Prunus persica (L.) Batsch) breeding progenies," Journal of Agricultural and Food Chemistry, vol. 57, no. 11, pp. 4586-4592, 2009.

[27] H. N. Rajha, N. Louka, N. Darra et al., "Multiple response optimization of high temperature, low time aqueous extraction process of phenolic compounds from grape byproducts," Journal of Food and Nutrition Sciences, vol. 5, pp. 351-360, 2014.

[28] M. N. Hasmida, A. R. N. Syukriah, M. S. Liza, and C. Y. M. Azizi, "Effect of different extraction techniques on total phenolic content and antioxidant activity of quercus infectoria galls," International Food Research Journal, vol. 21, no. 3, pp. 1039-1043, 2014.

[29] A. Arana-Sánchez, M. Estarrón-Espinosa, E. N. ObledoVázquez, E. Padilla-Camberos, R. Silva-Vázquez, and E. LugoCervantes, "Antimicrobial and antioxidant activities of Mexican oregano essential oils (Lippia graveolens H. B. K.) with different composition when microencapsulated in $\beta$-cyclodextrin," Letters in Applied Microbiology, vol. 50, no. 6, pp. 585-590, 2010.

[30] Z. Fang and B. Bhandari, "Encapsulation of polyphenols-a review," Trends in Food Science \& Technology, vol. 21, no. 10, pp. 510-523, 2010.

[31] Z. Zarai, E. Boujelbene, N. Ben Salem, Y. Gargouri, and A. Sayari, "Antioxidant and antimicrobial activities of various solvent extracts, piperine and piperic acid from Piper nigrum," LWT-Food Science and Technology, vol. 50, no. 2, pp. 634-641, 2013.

[32] S. Naz, S. Ahmad, S. A. Rasool, S. A. Sayeed, and R. Siddiqi, "Antibacterial activity directed isolation of compounds from Onosma hispidum," Microbiological Research, vol. 161, no. 1, pp. 43-48, 2006.

[33] A. D. Russell, "Similarities and differences in the responses of microorganisms to biocides," Journal of Antimicrobial Chemotherapy, vol. 52, no. 5, pp. 750-763, 2003.

[34] "Health Canada- Health Products and Food Branch," Lists of Permitted Food Additives, Government of Canada, 2016, http://www.hc-sc.gc.ca/fn-an/securit/addit/list/index-eng.php.

[35] M. J. R. Vaquero, M. R. Alberto, and M. C. M. de Nadra, "Antibacterial effect of phenolic compounds from different wines," Food Control, vol. 18, no. 2, pp. 93-101, 2007.

[36] M. Karamac, A. Kosiñska, and R. B. Pegg, "Comparison of radical-scavenging activities for selected phenolic acids," Polish Journal of Food and Nutrition Science, vol. 14, pp. 165-169, 2005. 


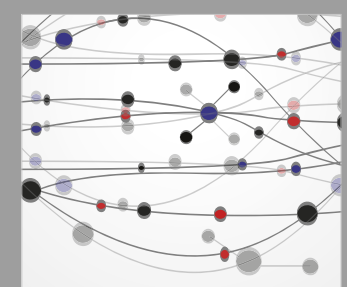

The Scientific World Journal
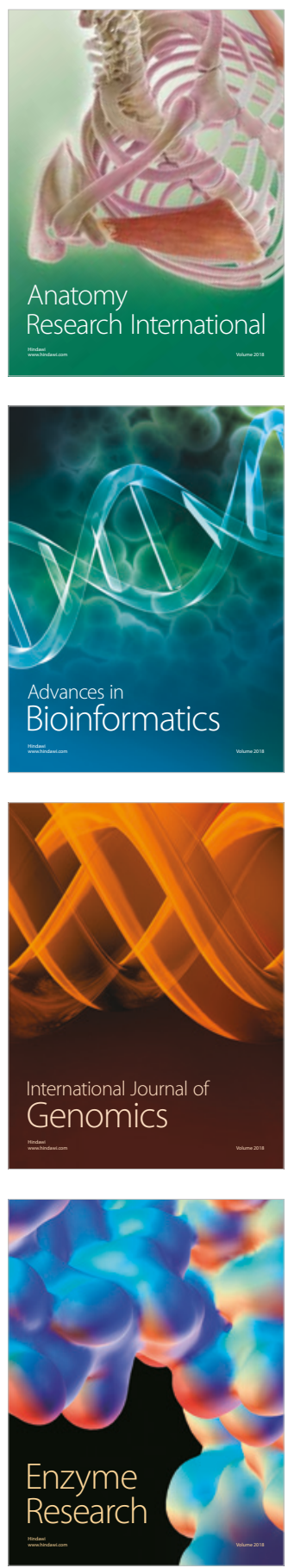
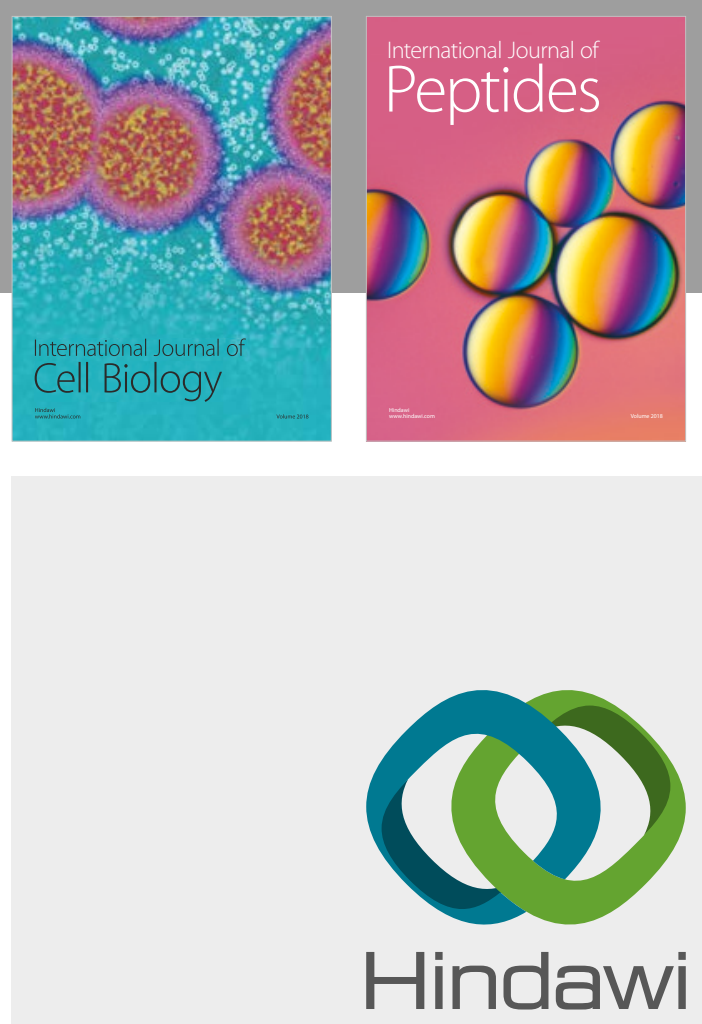

Submit your manuscripts at

www.hindawi.com
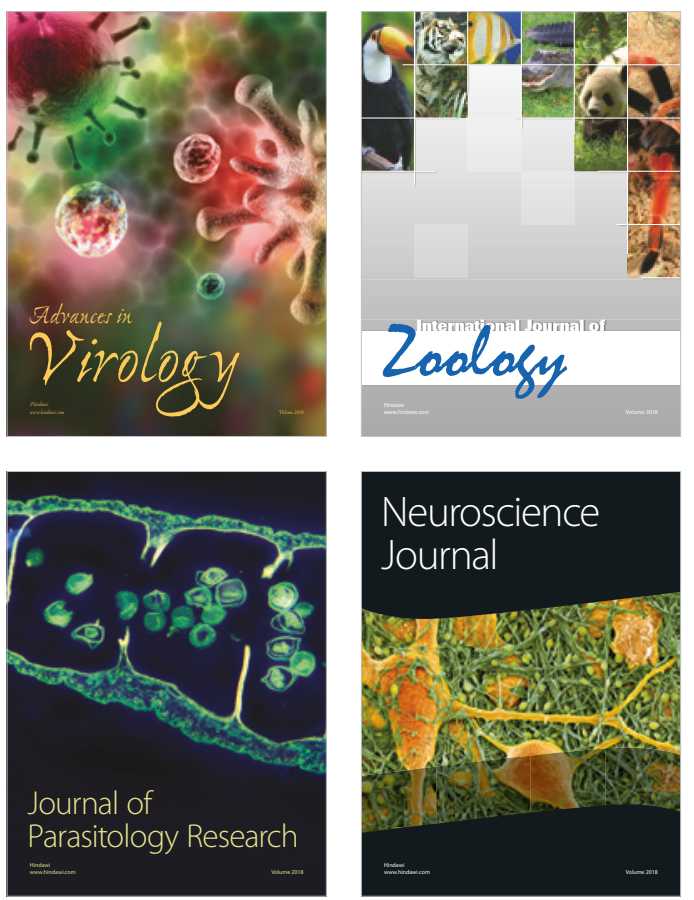
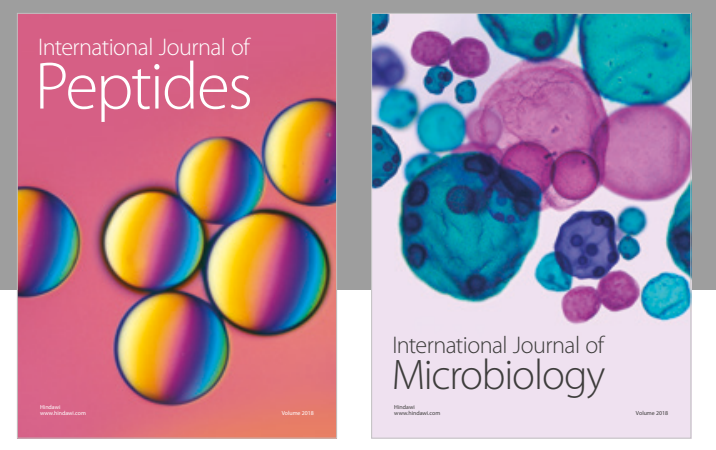

nternational Journal of Microbiology
Journal of
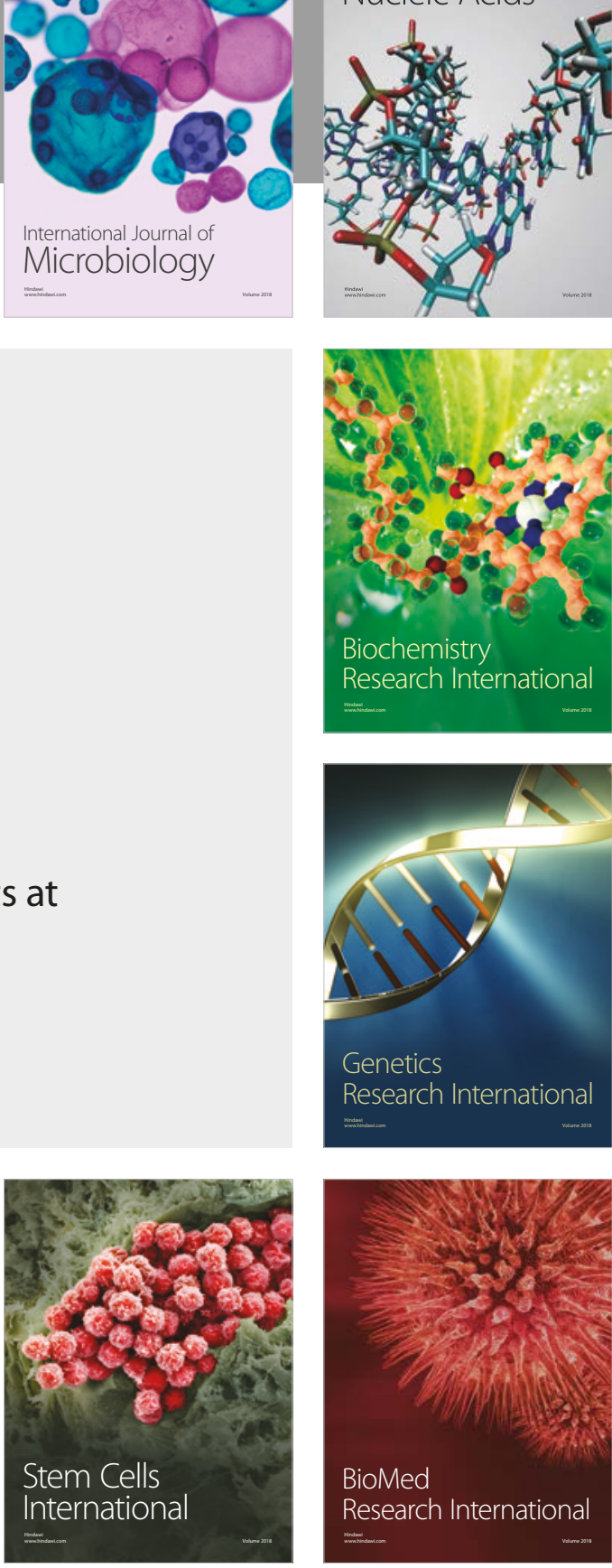
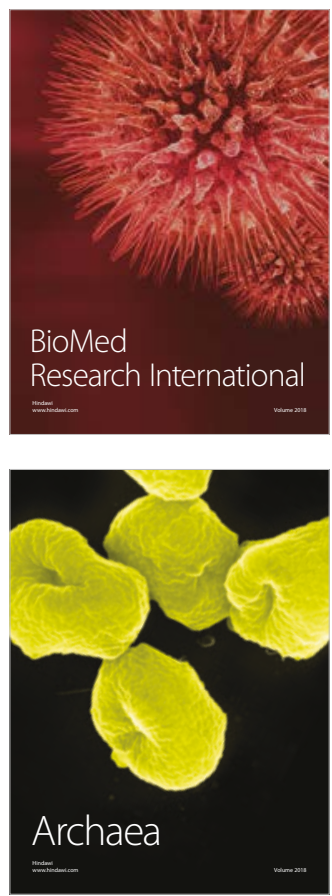